\title{
Retrospective Evalution of Pediatric Brucella Patients Followed and Family Screening with Household Members for Brucella Infection
}

\author{
Pediatrik Brusella Olgularının Retrospektif Değerlendirilmesi ve Yakın Temaslı \\ Aile Bireylerinde Brusella Enfeksiyonu Taraması
}

\author{
Fevzi Çağlar Özcanaslan'(ID), Ümmühan Çay²(ID), Özlem Özgür Gündeşlioğlu²(ID), illker Ünal(iD), Emine Kocabaş²(ID) \\ ${ }^{1}$ Division of Pediatric Neurology, Department of Pediatrics, Mersin University Faculty of Medicine, Mersin, Turkey \\ ${ }^{2}$ Division of Pediatric Infection, Çukurova University Faculty of Medicine, Adana, Turkey \\ ${ }^{3}$ Department of Biostatistic, Çukurova University Faculty of Medicine, Adana, Turkey
}

Cite this article as: Özcanaslan FÇ, Çay Ü, Özgür Gündeşlioğlu Ö, Ünal I, Kocabaş E. Retrospective evalution of pediatric brucella patients followed and family screening with household members for brucella infection. J Pediatr Inf 2021;15(2):e69-e74.

\section{Abstract}

Objective: In this study we aimed to analyse demographic and clinic properties, laboratory findings and efficiency of medical therapy of pediatric patients with Brucellosis followed at Çukurova University Faculty of Medicine, Pediatric Infection Diseases out patient and in patient clinic, and screening the households members of acute patients for occuring Brucella Infection.

Material and Methods: The files of 65 children with brucellosis were retrospectively reviewed for six years. Brucella scans, demographic and clinical characteristics of all patients included in the study and those with family screening were recorded. Tube agglutination test for brucella was studied in the sera of all patients and close family members. Serum tube aglutination test of all patients and household members were analysed at Çukurova University Faculty of Medicine Central Laboratory. The statistical analysis were made at Çukurova University Faculty of Medicine, Department of Biostatistic.

Results: Thirty-eight of 65 patients (58.5\%) were male and 27 of 65 patients $(41.5 \%)$ were female. Patients' age range was 9-198 months and mean age was 104 months. Elapsed time until brucella diagnosis was range between 3-150 days. The most common symptom was fever that observed in $81.5 \%$ patients. The most common physical examination finding was hepatosplenomegaly that observed in $20 \%$ patients. There was statistically significant decrease between seropositivity of brucella, ESH and CRP values before and after the treatment $(p<0.001)$. Success rate of triple antibiot-
Öz

Giriş: Bu araştırmada Çukurova Üniversitesi Tıp Fakültesi Çocuk Enfeksiyon Hastalıkları servis ve/veya polikliniğinde bruselloz tanısı almış çocuk hastaların demografik ve klinik özellikleri, laboratuvar bulguları ve uygulanan tedavinin etkinliğiyle yakın temaslı aile bireylerinin brusella enfeksiyonu gelişimi açısından değerlendirilmesi amaçlanmıştır.

Gereç ve Yöntemler: Altı yıllık zaman diliminde bruselloz tanısı almış 65 çocuk hastanın dosyaları geriye dönük olarak incelenmiştir. Çalışmaya alınan tüm hastaların ve bu hastalardan aile taraması yapılmış olanların brusella taramaları, demografik ve klinik özellikleri kaydedildi. Çalışmaya alınan 65 hastayla bu hastalardan yeni tanı alan 24'ünün yakın aile bireylerinin demografik ve klinik özellikleri kaydedildi. Tüm hasta ve yakın aile bireylerinin serum tüp aglütinasyon testi Çukurova Üniversitesi Tıp Fakültesi Merkez Laboratuvarında çalışıldı. İstatistiksel değerlendirme Çukurova Üniversitesi Tıp Fakültesi, Biyoistatistik Anabilim Dalında yapıldı.

Bulgular: Araştırmaya alınan 65 hastanın 38 (\%58.5)'i erkek, 27 (\%41.5)'si kızdı. Hastaların yaşları 9-198 ay arasında değişmekte ve yaş ortalaması 104 aydı. Bruselloz tanısına kadar geçen süre 3-150 gün arasında değişmekteydi. En sık belirti \%81.5 oranıyla hastada görülen ateş ve en sık rastlanan fizik muayene bulgusu da $\% 20$ hastada saptanan hepatosplenomegali idi. Tedavi öncesi Brucella seropozitivite oranları, eritrosit sedimentasyon hızı (ESH) ve C-reaktif protein (CRP) değerleri ile tedavi sonrası brusella seropozitivite oranları, ESH ve CRP değerleri istatistiksel olarak anlamlı bir azalma gösterdi $(p<0.001)$. Altı hafta süreyle yapılan 
ics treatment regimen during six weeks was $96.8 \%$. Seropositivity rate was found $18.2 \%$ in the household members of acute patients.

Conclusion: In our region, evaluating family history for brucella, raw milk and/or dairy products consumption in patients admitting to hospital with fever, arthralgia, hepatosplenomegaly, pancytopenia or bicytopenia has an important value for early diagnosis. Clinical and serological examination of close family members of patients with brucellosis may allow early diagnosis and treatment of possible close contact cases. Doing this study in a large segment of the population at risk in endemic countries for brucella like our country is critically important to provide early diagnosis and allow for early treatment.

Keywords: Brucella, family screening, child, laboratory findings

\section{Introduction}

Brucellosis is a substantive public health problem, which is commonly seen in the world and endemic in developing countries such as ours (1). Findings and symptoms of the disease may be diverse. It may show clinical diversity ranging from serology positivity detected coincidentally to severe clinical manifestations such as endocarditis and neurobrucellosis.

Zoonotic diseases like brucellosis may be common in individuals sharing the same socioeconomic conditions. Studies have shown that concurrent brucella infection may occur without symptoms and findings in family members consuming the same dairy products and sharing the same environment with index cases of brucellosis $(2,3)$. Therefore, close-contact screening based on acute brucella cases found in a region may enable the detection of new cases.

In this study, it was aimed to evaluate the clinical and epidemiological characteristics and laboratory findings of brucellosis and the efficiency of the treatment administered, and to assess close-contact family members in terms of brucella infection development.

\section{Materials and Methods}

In this study, the files of 65 pediatric cases diagnosed with brucellosis and followed in the ward and/or polyclinic of ... Medical Faculty Division of Pediatric Infection during a period of six years were retrospectively evaluated. Diagnosis in all patients was made by standard tube agglutination (STA) and/ or positive blood culture in the presence of clinical symptoms and findings such as fever, arthralgia, hepatosplenomegaly, and lymphadenopathy. Patients' demographics, clinical values, laboratory findings, and the treatment administered, consumption of raw milk and dairy products, history of husbandry, and information on brucella infection of close-contact family members were recorded.

Approval was obtained from the Ethics Board of the Faculty of Medicine. Serum samples taken from all patients were analyzed wit STA test at the center laboratory of Çukurova üçlü antibiyotik tedavisiyle başarı oranı \%96.8 idi. Yirmi dört hastanın 99 aile bireylerinde yapılan taramada Brusella seropozitivite oranı $\% 18.2$ olarak saptandı.

Sonuç: Bölgemizde ateş, eklem ağrısı, hepatosplenomegali, pansitopeni veya bisitopeni nedeniyle başvuran hastaların bruselloz yönünden aile öyküsünün alınması, çiğ süt ve/veya süt ürünü tüketiminin sorgulanması erken tanı açısından büyük önem taşımaktadır. Bruselloz tanısı alan hastaların yakın aile bireylerinin klinik ve serolojik olarak incelenmesi, olası yakın temaslı olguların da erken tanı ve tedavilerine olanak sağlayabilir. Bu araştırmanın bruselloz açııından endemik bir ülke olan ülkemizde geniş temaslı gruplarında yapılması erken tanı ve tedavi açısından büyük önem taşımaktadır.

Anahtar Kelimeler: Brusella, aile taraması, çocuk, laboratuvar bulguları

University Faculty of Medicine. Brucellosis diagnosis was made in patients and family members with a serum STA value of $\geq 1 / 160$. For Brucella hepatitis, a 1.5 fold higher value $(\geq 60$ $\mathrm{U} / \mathrm{ml}$ ) compared to the reference value of alanine aminotranspherase (ALT) was predicated on. Brucella in the cerebrospinal fluid (CSF) was determined by tube agglutination test and/or positive CSF culture.

The treatment regimen included rifampisin $(10 \mathrm{mg} / \mathrm{kg} /$ dose, oral 2 doses) and co-trimoxazole $(10 \mathrm{mg} / \mathrm{kg} / \mathrm{day}$, oral 2 doses) for 42 days, and gentamycin $(5 \mathrm{mg} / \mathrm{kg} /$ dose, single dose IM) for 5-7 days for children aged $\leq 8$ years, and rifampisin (10 mg/kg/dose, oral 2 doses) and doxycycline $(4 \mathrm{mg} / \mathrm{kg} /$ day, oral 2 doses) for 42 days and gentamycin $(5 \mathrm{mg} / \mathrm{kg} /$ day, single dose IM) for 5-7 days for children aged $>8$ years.

\section{Statistical Evaluation}

PAWS program was sued for data analysis. Categorical variables were expressed as number and percentage and continuous variables as mean and standard deviation (median and min-max when necessary).

Wilcoxon Signed rank test was used in the comparison of erythrocyte sedimentation rate (ESR) and C-reactive protein (CRP) pre- and post- treatment, and McNemar test was used to compare seropositivity rates. Statistical significance in all tests was set at $p<0.05$ ).

\section{Results}

Table 1 shows the demographic and clinical characteristics of 65 brucellosis patients. Fifty-eight point five percent of the patients were boys and $41.5 \%$ were girls. While $32 \%$ of the patients lived in the countryside, $67.7 \%$ lived in the city. Family or close circle of $38.5 \%$ of the patients had a history of active brucella infection. The duration between onset of complaints and brucellosis diagnosis of the patients was between 3 and 150 days, with a mean of 21 days. Twenty-two patients (33.8\%) fed farm animals. Ninety-two point three percent of the patients had a history of raw milk and/or dairy product consumption.

Symptoms and clinical findings of the patients at the time of presentation were shown in Table 2 . The most frequent 
Table 1. Demographics of pediatric cases with brucella

\begin{tabular}{|l|c|}
\hline Characteristics & $\mathbf{n}=\mathbf{6 5}$ \\
\hline Age (month) & $103.8 \pm 52.9$ \\
Mean \pm SD & 104 \\
Median & $9-198$ \\
\hline Range (min-max) & $38(58.5)$ \\
\hline $\begin{array}{l}\text { Sex } \\
\quad \text { Male, } n(\%)\end{array}$ & $27(41.5)$ \\
\hline Female, $\mathrm{n}(\%)$ & $21(32.3)$ \\
\hline $\begin{array}{l}\text { Living space } \\
\quad \text { City, } \mathrm{n}(\%)\end{array}$ & $44(67.7)$ \\
\hline Time passed until diagnosis (day) & $30.68 \pm 26.65$ \\
$\quad$ Mean \pm SD & 21 \\
$\quad$ Range (min-max) & $3-150$ \\
\hline Active brucella history in the family or immediate circle $(+)$ & $25(38.5)$ \\
$\mathrm{n}(\%)$ & $22(33.8)$ \\
\hline $\begin{array}{l}\text { History of husbandry ( +) } \\
\mathrm{n}(\%)\end{array}$ & $60(92.3)$ \\
\hline $\begin{array}{l}\text { History of raw milk and dairy products consumption }(+) \\
\mathrm{n}(\%)\end{array}$ & \\
\hline
\end{tabular}

Table 2. Clinical characteristics of pediatric patients diagnosed with brucella

\begin{tabular}{|c|c|}
\hline Symtopms & $n=65$ \\
\hline Fever (+), n (\%) & $53(81.5)$ \\
\hline $\begin{array}{l}\text { Duration of fever before diagnosis (day) } \\
\text { Mean } \pm \text { SD } \\
\text { Median } \\
\text { Range (min-max) }\end{array}$ & $\begin{array}{c}27.64 \pm 22 \\
20 \\
3-90\end{array}$ \\
\hline Fatigue (+), n (\%) & $50(76.9)$ \\
\hline Loss of appetite (+), n (\%) & $46(70.8)$ \\
\hline Night sweating (+), n (\%) & $30(46.2)$ \\
\hline Weight loss (+), n (\%) & $22(33.8)$ \\
\hline Joint pain (+), n (\%) & $25(38.5)$ \\
\hline Hepatitis (+), n (\%) & $2(3.1)$ \\
\hline Diplopia (+), n (\%) & $2(3.1)$ \\
\hline \multicolumn{2}{|l|}{ Findings } \\
\hline Fever $\geq 38^{\circ} \mathrm{C}(+), \mathrm{n}(\%)$ & $4(6.2)$ \\
\hline Lymphadenopathy (+), n (\%) & $8(12.3)$ \\
\hline Hepatosplenomegaly (+), n (\%) & $13(20)$ \\
\hline Joint tenderness (+), n (\%) & $12(18.5)$ \\
\hline Joint swelling (+), n (\%) & $5(7.7)$ \\
\hline Temperature rise on the joint (+), n (\%) & $3(4.6)$ \\
\hline Limited joint movement (+), n (\%) & $6(9.2)$ \\
\hline Atypical walk (+), n (\%) & $1(1.5)$ \\
\hline Deviation of the eye inwards, $\mathrm{n}(\%)$ & $1(1.5)$ \\
\hline
\end{tabular}

symptom was fever with $81.5 \%$, followed by fatigue, loss of appetite, night sweating, and joint pain. The most common physical examination finding was hepatosplenomegaly with $20 \%$, followed by joint tenderness, lymphadenopathy, and limited joint movement.

Leucocyte count, mean platelet count and mean Hct value at the time of diagnosis in 65 patients were found respectively as $2.1-18.9 \times 10^{3} / \mathrm{mm}^{3}, 2.4 \pm 1.25 \times 10^{5} / \mathrm{mm}^{3}$, and 32.72 $\pm 5.41 \%$. Serum aspartate aminotranspherase (AST) and ALT values were studied in all 65 patients. In 24 (37.5\%) patients, transaminase value was found higher than the reference value. Brucella hepatitis was determined in 15 (23.5\%) of the cases. AST and ALT values in one of the patients were found as $1918 \mathrm{U} / \mathrm{L}$ and $941 \mathrm{U} / \mathrm{L}$, respectively. AST and ALT values of this patient returned to normal during the course of the treatment. ESH value was higher than $20 \mathrm{~mm} / \mathrm{h}$ in $43 \%$ of the patients. CRP value of the patients was higher than the reference value in $50.8 \%$ of the patients. Growth was detected in $22(47.8 \%)$ of 46 patients from whom blood culture was taken. All of the growing microorganism were B. melitensis (Table 3 ). Abdominal ultrasonography (USG) was performed in 27 of 65 patients (41.5\%). Hepatomegaly was detected in three (11.1\%) patients, splenomegaly in 10 (37\%) and hepatosplenomegaly in $9(33.3 \%)$ patients.

Table 3. Laboratory findings of the pediatric patients diagnosed with brucella at the time of diagnosis

\begin{tabular}{|c|c|}
\hline Laboratory characteristics & \\
\hline $\begin{array}{l}\text { Leucocyte count }\left(\times 10^{3} / \mathrm{mm}^{3}\right)(\mathrm{n}=65) \\
\text { Mean } \pm \mathrm{SD} \\
\text { Median } \\
\text { Range (min-max) }\end{array}$ & $\begin{array}{c}7 \pm 3.04 \\
7.1 \\
2.1-18.9\end{array}$ \\
\hline $\begin{array}{l}\text { Platelet count }\left(\times 10^{5} / \mathrm{mm}^{3}\right)(\mathrm{n}=65) \\
\text { Mean } \pm \mathrm{SD} \\
\text { Median } \\
\text { Range (min-max) }\end{array}$ & $\begin{array}{c}2.4 \pm 1.25 \\
2.3 \\
0.05-6.2\end{array}$ \\
\hline $\begin{array}{l}\text { Hct }(\%)(n=65) \\
\text { Mean } \pm S D \\
\text { Median } \\
\text { Range (min-max) }\end{array}$ & $\begin{array}{c}32.72 \pm 5.41 \\
33.3 \\
15-46\end{array}$ \\
\hline $\begin{array}{l}\text { ESH }(\mathrm{mm} / \mathrm{h})(\mathrm{n}=65) \\
<20, \mathrm{n}(\%) \\
\geq 20, \mathrm{n}(\%)\end{array}$ & $\begin{array}{l}37(57) \\
28(43)\end{array}$ \\
\hline $\begin{array}{l}\operatorname{CRP}(\mathrm{mg} / \mathrm{L})(\mathrm{n}=63) \\
<8.2, \mathrm{n}(\%) \\
\geq 8.2, \mathrm{n}(\%)\end{array}$ & $\begin{array}{l}31(49.2) \\
32(50.8)\end{array}$ \\
\hline $\begin{array}{l}\text { ALT }(U / L)(n=64) \\
<40, n(\%) \\
40-60, n(\%) \\
\geq 60, n(\%)\end{array}$ & $\begin{array}{c}40(62.5) \\
9(14) \\
15(23.5)\end{array}$ \\
\hline Growth in blood culture $(+)(n=46)$ & $22(47.8)$ \\
\hline
\end{tabular}


Table 4. Hematologic findings of the pediatric patients diagnosed with brucella at the time of diagnosis

\begin{tabular}{|l|c|}
\hline Hematologic characteristics & $\mathbf{n}=\mathbf{6 5}$ \\
\hline Hematologic involvement rate (\%) & $(29.2)$ \\
\hline Anemia, $\mathrm{n}(\%)$ & $40(61.5)$ \\
\hline Leukocytosis, $\mathrm{n}(\%)$ & $3(4.6)$ \\
\hline Leucopenia, $\mathrm{n}(\%)$ & $14(21.5)$ \\
\hline Thrombocytopenia, $\mathrm{n}(\%)$ & $14(21.5)$ \\
\hline Thrombocytosis, $\mathrm{n}(\%)$ & $5(7.7)$ \\
\hline Pansitopenia, $\mathrm{n}(\%)$ & $8(12.3)$ \\
\hline
\end{tabular}

Leucocyte, platelet, and hct values were evaluated according to age-specific normal values in complete blood count. Most commonly anemia followed by neutropenia, thrombocytopenia, pancytopenia, thrombocytosis, leukocytosis were detected in all patients, and hematologic involvement rate was found as $29.2 \%$ (Table 4 ).

Treatments of the 62 patients out of 65 were administered as stated in the Material and Methods section. Treatment combinations used in the treatment of brucellosis patients were rifampisin + co-trimoxazole + gentamycin in $44.6 \%$ of the patients, rifampisin + co-trimoxazole in $1.5 \%$ and rifampisin + doxycycline + gentamycin in $49.3 \%$. Only the treatment of 3 patients was regulated individually due to side effects of the drugs.

Brucella STA test seropositivity rates $(S T A \geq 1 / 160)$ and mean ESH and CRP values were assessed pre- and post-treatment (Table 5). While seropositivity was detected in 63 of the 65 patients (96.9\%), following treatment, seropositivity was found in 23 of 54 patients $(42.6 \%)(p<0.001)$. While mean ESH was $22.17 \pm 20.11 \mathrm{~mm} / \mathrm{h}$ in 65 patients before treatment, it was $7.96 \pm 7.56 \mathrm{~mm} / \mathrm{h}$ in 54 patients after treatment $(\mathrm{p}<$ 0.001 ). While mean CRP was $16.53 \pm 19.4 \mathrm{mg} / \mathrm{dl}$ in 63 patients before treatment, it was $4.79 \pm 4.51 \mathrm{mg} / \mathrm{dl}$ after treatment $(p<$ $0.001)$. To conclude, a statistically significant decrease was established in ESH, CRP values and STA test seropositivity rates before and after treatment.

There was a total of 307 close-contact family members of 65 cases. In 16 (24.6\%) of the 99 (32.2\%) family members of 24 index patients (36.9\%) who were screened, similar complaints like fever, joint pain, and fatigue were observed at the time of diagnosis. Seropositivity (STA $\geq 1 / 160$ ) was detected in 18 (18.2\%) close-contact family members of 9 cases.

\section{Discussion}

Brucellosis is an important cause of economic loss and public health problem in many developing countries and one of the zoonotic diseases seen widely in the world with a high morbidity for both humans and animals $(1,4)$. The disease in our country is seen in both sexes and at every age. Age range has been found as six months to 16 years in studies involving the pediatric age group (5-10). In a study by Buzgan et al. comprising 1028 cases, it has been reported that $53.42 \%$ of the cases were between 13-34 years of age (6). Age range in our study was found as nine months to 16.5 years, and these values were consistent with the age range found in other studies including pediatric cases.

Most commonly, mode of transmission is through cheese, custard and butter made using raw milk. In places where milk is consumed by being pasteurized first, transmission through direct contact is at the forefront comparted to oral transmission (1). In our study, raw milk and/or use of unpasteurized dairy products was detected in $92.3 \%$ of our cases. It is seen that studies have reported a rate between $63.6 \%$ and $94.6 \%$ for raw milk and/or unpasteurized dairy products consumption (6-11). Brucella infection may be transmitted from bother to the newborn and infant congenitally and moreover, breastmilk may be infected through the consumption of infected animal products and inhalation of infected particles. In our study, we detected that the mode of transmission in our 9-month-old case was through the consumption of unpasteurized animal products.

Diagnosis and treatment may be delayed in brucellosis since its symptoms and findings can be easily confused with those of other diseases. In our study, the most common symptom was fever, followed by fatigue, loss of appetite, night sweating, and joint pain. Arthralgia and hepatosplenomegaly were most commonly detected on physical examination. Similar results have been reported in case series in the literature $(6,7,9,11)$. Mean time of diagnosis between the onset of complaints and brucellosis diagnosis was 21 days, and this duration can extend to 150 days. Diversity of clinical symptoms,

Table 5. Comparison of ESH, CRP and STA values of the pediatric patients diagnosed with brucella before and after treatment

\begin{tabular}{|l|c|c|c|}
\hline & Before treatment & After treatment & p \\
\hline ESH $(\mathrm{mm} / \mathrm{h})$ & $(\mathrm{n}=65)$ & $(\mathrm{n}=54)$ & $<0.001$ \\
Mean $\pm \mathrm{SD}$ & $22.17 \pm 20.11$ & $7.96 \pm 7.56$ & $<0.001$ \\
\hline CRP $(\mathrm{mg} / \mathrm{dl})$ & $(\mathrm{n}=63)$ & $(\mathrm{n}=53)$ & \\
Mean \pm SD & $16.53 \pm 19.4$ & $(\mathrm{n}=54)$ & $<0.51$ \\
\hline STA $\geq 1 / 160$ & $(\mathrm{n}=65)$ & $23(42.6)$ & $<0.001$ \\
$\mathrm{n}(\%)$ & $63(96.9)$ & & \\
\hline
\end{tabular}


and the nonspecific and mostly asymptomatic nature of the diseases lead to late diagnoses. Late diagnosis in brucellosis may cause a serious increase in morbidity and mortality. Family history, farm animal breeding, consumption of unpasteurized milk and dairy products must be questioned and brucellosis must be considered in patients with clinical symptoms including fever, arthralgia, hepatosplenomegaly, bicytopenia, and pancytopenia.

Routine laboratory investigations in brucellosis are usually not specific to the disease. In a study investigating 48 brucellosis cases with hematologic findings in our country, anemia, leucopenia, thrombocytopenia, and pancytopenia were detected at a rate of $81 \%, 58 \%, 46 \%$, and $21 \%$, respectively (12). In a study consisting 97 pediatric cases, anemia was detected at a rate of $52.6 \%$, leucopenia $9.3 \%$, leukocytosis $11.3 \%$, thrombocytosis $10.3 \%$, and pancytopenia $6.2 \%(10)$. In our study, hematologic involvement was $29.2 \%$, anemia $61.5 \%$, leucopenia $21.5 \%$, leukocytosis $4.6 \%$, thrombocytopenia $21.5 \%$, thrombocytosis $7.7 \%$, and pancytopenia $7.7 \%$, all consistent with the literature. Acute phase reactants are not diagnostic but supportive in brucellosis cases (8-10). They can be normal or slightly elevated. In our study, ESH elevation was detected at a rate of $43 \%$ and CRP elevation at a rate of $50.8 \%$.

Brucella infections may manifest with specific organ involvement beside or without acute systemic symptoms. The liver is frequently involved in brucellosis. Liver enzymes usually show slight elevation. Studies have demonstrated transaminase elevation and hepatitis at a rate of $18.3-55 \%$ and $2.7-33.3 \%$, respectively $(6,13,14)$. In our study, transaminase elevation was at a rate of $37.5 \%$ and hepatitis at a rate of $23.5 \%$. These findings were consistent with those of the literature. The most common local disease caused by Brucella spp is osteoarticular involvement. In the literature, osteoarticular involvement is seen in $20-85 \%$ of the cases $(15-16)$. While joint pain was found in $38.5 \%$ of our cases, additional findings suggestive of arthritis such as joint swelling and limited joint movement were found in $20 \%$ of the cases. Genitourinary complications are seen at a rate of $1-20 \%$ in brucellosis (16\%). In a study conducted on children, epididymoorchitis has been reported at a rate of $5.3 \%$ (17). We did not find epididymoorchitis in our patients. Neurobrucellosis is rare in children. Involvement of the central nervous system is seen in approximately $1 \%$ of the cases (18). We detected neurobrucellosis in 1 patient $(1.5 \%)$ presenting with deviation of the eyes inwards, and this rate was consistent with the literature.

Zoonotic diseases like brucellosis may be more common among individuals sharing the same socio-economic conditions (19). In endemic regions, brucellosis cases have been reported in individuals of the same family (20). In a study by Roushan et al. including 469 cases, the rate of brucellosis in family members has been found as $9.6 \%$ (21). In a study by
Çiftdogan et al., brucellosis prevalence in index cases has been detected as $36.8 \%$ (9). In a study by Gündeşlioglu including 145 cases, this rate has been confirmed as $39.2 \%$ in family members (7). In studies conducted on close-contact family members in the literature, seropositivity rates for brucella ranged between $2.9-39.2 \%$ (7,22-24). In our study, brucella seropositivity (36.9\%) was detected in 9 close-contact family members of 24 index cases in whom family screening was performed. STA test was positive for Brucella in 18 (18.2\%) of 99 close-contact family members of a total of 9 index cases. This rate varies in the literature. It is considered to be detected at a higher rate in endemic regions, and active brucellosis history in the family or immediate circle is important in diagnosis. Therefore, close-contact screening based on acute brucella cases found in a region may enable the detection of new cases.

To conclude, questioning family history in patients presenting due to fever, hepatosplenomegaly, pancytopenia or bicytopenia in our region and farming/husbandry and consumption of raw milk and raw dairy products is important in terms of early diagnosis. Clinical and serologic investigation of close family members of the patients diagnosed with brucellosis may enable the early diagnosis and treatment of close-contact cases. Screening wide contact groups in an endemic country like ours is important in terms of early diagnosis and treatment.

Ethics Committe Approval: The approval for this study was obtained from Çukurova University Faculty of Medicine Ethics Committee.

Informed Consent: Patient consent was obtained.

Peer-review: Externally peer-reviewed.

Author Contributions: Concept - EK, FÇÖ; Design - ÜÇ; Supervision - EK, ÖOG; Resource - EK, FÇÖ; Data Collection and/or Processing FÇÖ, ÖOG; Analysis and/or Interpretation - IÜ, EK; Literature Search - FÇÖ, ÜÇ; Writing - FÇÖ, EK; Critical Review - ÜÇ, EK.

Conflict of Interest: All authors declare that they have no conflicts of interest or funding to disclose.

Financial Disclosure: The authors declared that this study has received no financial support.

\section{References}

1. Sözen TH. Bruselloz. In: Willke Topçu A, Söyletir G, Doğanay M (eds). Infeksiyon Hastalıkları ve Mikrobiyolojisi. Ankara: Nobel Tıp Kitabevleri, 2002:636-42. [CrossRef]

2. Edward JY. Brucella species. In: Mandell GL, Douglas RG, Bennet JE (eds). Principles and Practice of Infectious Diseases. $5^{\text {th }}$ ed. Philedelphia: Churchill Livingstone, 2000:2386-93. [CrossRef]

3. Eduardo G, Carlos C. Brucella. In: Gorbach SL, Barlett JG, Blacklow NR (eds). Infectious Diseases. $2^{\text {nd }}$ ed. Philedelphia: W.B. Saunders Company, 1998:1837-45. [CrossRef] 
4. Jennings GJ, Hajjeh RA, Girgis FY, Fadeel MA, Maksoud MA, Wasfy MO, et al. Brucellosis as a cause of acute febrile illness in Egypt. Trans $R$ Soc Trop Med Hyg 2007; 101:707. [CrossRef]

5. Saçar S, Cenger Hırçın D, Toprak S, Demir M, Turgut H. Otuz bruselloz olgusunun klinik değerlendirilmesi. Turk J Infect 2008;22(1):11-14. [CrossRef]

6. Buzgan T, Karahocagil MK, Irmak H, Baran Al, Karsen H, Evirgen O, Akdeniz H. Clinical manifestations and complications in 1028 cases of brusellozis: a retrospective evaluation andreview of the literature. Int J Infect Dis 2010;14:469-78. [CrossRef]

7. Gündeşlioğlu ÖÖ. Brucella infection in children: Evaluation of 148 pediatric patients. J Clin Anal Med 2019;10(1):99-103. [CrossRef]

8. Jia B, Zhang F, Lu Y, Zhang W, Li J, Zhang Y, et al. The clinical features of 590 patients with brucellosis in Xinjiang, China with the emphasis on the treatment of complications. Plos Negl Trop Dis 2017;11(5):0005577. [CrossRef]

9. Çiftdoğan DY, Aslan S. Unrecognized pediatric and adult family members of children with acute brucellosis. Braz J Infect Dis 2017;21:520-4. [CrossRef]

10. Yoldaş T, Tezer H, Parlakay AO, Saylı TR. Clinical and laboratory findings of 97 pediatric brucellosis patients in central Turkey. J Microbiol Immun Infect 2015;48:446-9. [CrossRef]

11. Çelebi S, Hacımustafaoğlu M, Demirtaş F, Salı E, GülÜ, Özel M. Çocukluk çağında bruselloz. J Pediatr Inf 2011;5:59-62. [CrossRef]

12. Demir C, Karahocagil MK, Esen R, Atmaca M, Gönüllü H, Akdeniz H. Bone marrow biopsy findings in brucellosis patients with hematologic abnormalities. Chin Med J (Engl) 2012;125(11):1871-6. [CrossRef]

13. Kaya O, Akçam FZ, Avşar K, Tığlı A, Yaylı G. Bruselloz:75 olgunun klinik ve laboratuvar verilerinin değerlendirilmesi. Turkiye Klinikleri J Med Sci 2006;26:623-9. [CrossRef]

14. Tanir G, Tufekci SB, Tuygun N. Presentation, complication, and treatment outcome of brusellozis in Turkish children. Pediatr Int 2009;51:1149. [CrossRef]
15. Young EJ. Brucella species. In Mandell GL, Bennett JE, Dolin R (eds). Principles and practice of infectious diseases. $6^{\text {th }}$ ed. Philadelphia: Churchill Livingstone, 2005 pp: 2669-72. [CrossRef]

16. Doğanay M, Alp Meşe E. Bruselloz. In: Willke Topçu A, Söyletir G, Doğanay $M$ (eds). Infeksiyon Hastalıkları ve Mikrobiyolojisi. 3. Baskı, Ankara: Nobel Tip Kitabevleri, 2008:897-909. [CrossRef]

17. Madkour MM. Bruselloz. Istanbul: Nobel Tip Kitabevleri, 2008. [CrossRef]

18. Schutze GE, Jacobs RF. Brucella. In: Behrman RE, Kliegman RM, Jenson $H B$ (eds). Nelson textbook of pediatrics. $17^{\text {th }}$ ed. Philadelphia: WB Saunders, 2004:939-41. [CrossRef]

19. Koçoğlu E, Karabay O, Ince N. Bruselloz için serolojik taramanın değeri. Türk Mikrobiyol Cem Derg 2008;38(1):23-6. [CrossRef]

20. Yüce A, Alp-Çavuş S. Türkiye'de Bruselloz: Genel bakış. Klimik 2006;19(3):87-97. [CrossRef]

21. Hasanjani Roushan MR, Mohrez M, Smailnejad Gangi SM, Solemani Amiri MJ, Hajiahmadi M. Epidemiological featuresand clinical manifestations in 469 adult patients with brucellosis in Babol, Northern Iran. Epidemiol Infect 2004;132:1109-14. [CrossRef]

22. Mendoza-Nunez M, Maximillan M, Franco MP, Maas SM, Castenada $M L$, Bonifacio N, et al. Brusellozis in household members of brucella patients residing in a large urban setting in Peru. Am J Trop Med Hyg 2008;78(4):595-8. [CrossRef]

23. Deniz S, Baykam N, Celikbas A, Yilmaz SM, Guzel TC, Dokuzoguz B, et al. Screenin household members of acute brucellosis cases in endemic areasand risk factorsfor brucellosis. Vector Borne Zoonotic Dis 2015;15(8):468-72. [CrossRef]

24. Sofian M, Safaeipour L, Aghakhani A, Sharif MR, Banifazl M, Sharif A, et al.Screening of family members of patients with acute brucellosis in an endemic area of Iran. Iran J Microbiol 2013;5(3):215-9. [CrossRef]

25. Bosilkovski M. Brucellosis: Epidemiology, microbiology, clinical manifestations, and diagnosis. Available from: https://www.uptodate.com/ contents/Brucellosis-Epidemiology-microbiology-clinical-manifestations-and-diagnosis (Accessed date: 18 Jan 2021). [CrossRef] 